\title{
Can Climate and Environmental Factors Putatively Increase SARS-Cov2 Transmission Risks?
}

\author{
Elizabeth Ferreira Rangel ${ }^{1 *}$, Margarete Martins dos Santos Afonso', Adriana Sotero-Mar- \\ tins $^{2}$, Aline Campos ${ }^{3}$, Wagner Nazário Coelho ${ }^{2}$, Eric Lopes da Gama ${ }^{4}$, Geane Lopes Flores ${ }^{4}$, \\ Marilda Mendonça Siqueira ${ }^{4}$ and Maria de Lourdes Aguiar-Oliveira ${ }^{4}$ \\ ${ }^{1}$ Interdisciplinary Entomological Surveillance Laboratory in Diptera and Hemiptera, Oswaldo Cruz Institute, National Institute of Science and Technol- \\ ogy on Climate Change, Brazil
}

${ }^{2}$ Department of Sanitation and Environmental Health, National School of Public Health Sergio Arouca (ENSP), Brazil

${ }^{3}$ Department of Health, State Center for Health Surveillance, Brazil

${ }^{4}$ Laboratory of Respiratory Viruses and Measles, Oswaldo Cruz Institute, Brazil National Reference Laboratory for Influenza and COVID-19 for the Brazilian Ministry of Health (MoH) and World Health Organization (WHO), Brazil

*Corresponding author: Elizabeth Ferreira Rangel, Instituto Oswaldo Cruz/ Fundação Oswaldo Cruz, Rio de Janeiro, Rio de Janeiro, Brazil.

To Cite This Article: Elizabeth Ferreira R, Margarete Martins dos Santos A, Adriana Sotero-Martins, Aline Campos, Wagner Nazário C, et al., Can Climate and Environmental Factors Putatively Increase SARS-Cov2 Transmission Risks?. Am J Biomed Sci \& Res. 2021 - 11(4). AJBSR. MS.ID.001647. DOI: 10.34297/AJBSR.2021.11.001647.

Received: 䟧 December 19, 2020; Published: 眥 January 08, 2021

\begin{abstract}
After the identification of the first SARS-COV-2 infected cases in China, the virus was rapidly disseminated among the distinct continents and the COVID-19 pandemics was announced by the WHO in March 2020. Over time, the epidemiological sceneries varied among countries, according to the adopted mitigation measures and epidemic phase. Recently, a recrudescence of the epidemics has been observed in distinct countries. SARSCoV-2 can be transmitted by direct or indirect contact. The viral RNA has been detected in stool and other clinical specimens from infected patients and a putative fecal-oral transmission has been argued. Viruses are shed in human excreta, further disposed into the sewerage system or into the environment, in poor sanitation settings. Thus, SARS-CoV-2 RNA has been regularly detected in wastewater and surface water impacted by the direct discharge of sewage. Some studies have reported an association between climatic parameters and an increase in COVID-19 incidence. However, conclusive evidence based in full seasons is needed so far.

This mini-review briefly discusses the putative role of climate and environmental factors on SARS-CoV-2 exposure, transmission and circulation patterns. Moreover, some additional challenges in middle and low-income settings are highlighted. Efforts must be driven to categorically understand the relationships between SARS-CoV-2 infection, circulation patterns and climate parameters, as the putative implications of viral persistence and viability in distinct environmental matrices. This information is crucial for COVID-19 control and prevention, especially in middle and low-income settings, already wedged by social inequality, inadequate sanitation and deficient healthcare admission.
\end{abstract}

Keywords: SARS-COV-2 transmission; COVID-19; Climate; Wastewater; Surface water; Public health

\section{Introduction}

After the identification of the first severe acute respiratory syndrome coronavirus 2 (SARS-COV-2) infected cases in Wuhan, China, in December 2019 [1,2], the virus was rapidly disseminated among the distinct continents and led the World Health Organization to announce the COVID-19 pandemics in March 2020 [3]. Over time, the epidemiological sceneries varied among countries, according to the adopted mitigation measures and epidemic phase [4-7]. Recently, a recrudescence of the epidemics has been observed in Europe [8] and in the Americas, where the highest new case and deaths figures have been reported in the United States, followed by Brazil, Mexico, Columbia and Argentina [9]. 
SARS-CoV-2 infected droplets and aerosols are released from symptomatic or asymptomatic subjects during events such as coughing, sneezing and talking. Afterwards, the virus can infect new hosts via direct or indirect contact. The close contact favors the inhalation or direct exposure of mucous membranes from susceptible persons to infected discharged particles. Viral exposure can also occur by the contact with contaminated surfaces or fomites [10], where the virus is able to remain viable and infectious for hours or even days, depending on the concentration of the inoculum and the nature of the investigated surfaces [11-13]. Increasing evidence suggests a role of viral airborne transmission via aerosols [11,14$18]$, particularly in indoor and crowded settings $[18,19]$.

SARS-CoV-2 RNA has been detected in stool and other clinical specimens from infected patients [20-23], despite the presence of gastrointestinal symptoms [24]. Although, information on viable and infective viruses in feces is still limited $[21,23,25,26]$, this context raised the current debate on a putative role if fecal oral transmission $[23,27,28]$. As viruses are shed in human excreta $[29,30]$ - are further disposed into the sewerage system or directly into the environment, in poor sanitation settings - viral RNA has been detected in waste- and polluted surface water [31-36]. Under the climate perspective, some studies have reported an association between climatic parameters and an increase in COVID-19 incidence [37,37-40]. However, conclusive evidence based in full seasons is needed so far. In addition, confounding factors - such as socioeconomic variables - are also critical, specially in middle and low income areas [41]. This mini-review briefly discusses the putative role of climate and environmental factors on SARSCoV-2 exposure, transmission and circulation patterns. Moreover, some additional challenges in middle and low-income settings are highlighted.

\section{SARS-Cov-2 and the Environment}

SARS-CoV-1 can survive for 4 days in diarrheal stool samples $[42,43]$. Other coronaviruses ( $\mathrm{CoV}$ ) remain infectious in water and sewage for days to weeks $[44,45]$ and their inactivation depends on temperature, level of organic materials, UV exposure and microbial community [46-48]. Thermodynamic studies revealed that SARS$\mathrm{CoV}-2$ is able to survive for approximately 10 hours in environments under a temperature of $35^{\circ} \mathrm{C}$ [49] and, in laboratory conditions, the virus is highly stable at $4^{\circ} \mathrm{C}[50]$. At room temperature $\left(22^{\circ} \mathrm{C}\right)$, viruses remain viable for 3 days in wet or dry environments, despite a wide range of $\mathrm{pH}$ values [51]. As other CoV, SARS-CoV-2 is susceptible to antiseptics containing ethanol, and disinfectants with chlorine or bleach $[50,52,53]$. A recent study had shown that treated wastewater effluents present a 100 times reduction in SARS-CoV-2 load compared to the corresponding raw wastewater samples [54].
Worldwide, SARS-CoV-2 RNA has been regularly detected in wastewater [31] and rivers impacted by the direct sewage discharge of sewage $[35,55,56]$. In this context, it is essential to emphasize that the detection of viral nucleic acid does not indicate the presence of active and infectious SARS-CoV-2. To date, there is no evidence of viral infection through drinking water, food or other matrices $[48,57]$ and, so far, the studies addressing the SARS-CoV-2 viability in untreated and treated wastewater, surface water and soil were not able to recover and demonstrate the presence of infectious viruses in these samples $[35,56,58,59]$. Nonetheless, cumulative evidence is critical to effectively understand the putative role of these elements as potential sources of viral exposure [27,47,60-65], particularly in limited/poor sanitation settings, which comprise about a third of the global population [66]. In these backgrounds, waterways are used as open sewers and sources of water for domestic purposes $[61,62]$ and the proximity of latrines or septic tanks and surface or groundwater uses to be common [66].

Under a complementary perspective, the increasing frequency of strong rainfalls, storms and flooding, as a consequence of climatic changes [67], adds additional challenges to this scenario. Excessive water volume can overload sewer's and wastewater treatment plants' capacity, resulting in overflows and sewage discharge, threatening the water distribution systems, water sources and surface waters [68]. Hence, the presence of viral RNA in wastewater demands additional information to elucidate a supposed viral role in water pollution $[47,62]$. Lastly, considering that distinct animal hosts are permissive to SARS-CoV-2 infection [69-72] and that spillover events are frequent among $\mathrm{CoV}$ [73], the introduction of viable SARS-CoV-2 into natural aquatic environments could putatively affect livestock and wildlife. Hence, there are still knowledge caveats to be fulfilled, demanding further research $[27,31,65]$.

\section{SARS-Cov- 2 and the Climate}

Mostly, respiratory viruses (RV) present seasonal patterns of circulation [74-79]. The seasonality of RV infections can be mainly attributed to the environmental and weather effects on on viral circulation, as to factors associated with host's behavior and immune response [80]. In temperate regions, an increase in influenza, respiratory syncytial virus (RSV) and seasonal CoV activities has been associated with cold and dry winters. In contrast, in the tropical and subtropical regions, epidemics uses to occur in rainy seasons or along the year [74,75,81-89]. Time series analyses suggest that the likelihood of airborne transmission is favored by the presence of low relative humidity and lower temperature conditions [90-92]. These events have been attributed to the effects of these variables on viral stability and transmissibility. RV are able to survive longer on surfaces or in droplets in a context of cold and dry air $[75,93]$ and the mechanism of virus survival in the cool- 
dry or humid-rainy conditions is determined by the presence of salts and proteins in the respiratory droplets [94]. Thus, climate conditions may play a crucial role in driving epidemics caused by these viruses. Under this perspective, a key question consists on the putative influence of environmental and climatic variables on the seasonality and dynamics of SARS-CoV-2 epidemics.

Some authors reported a positive association between climate parameters and COVID-19 incidence [38-40]. A positive correlation between low relative humidity and disease severity was reported among Chinese and Europena hospitalized patients [38], in line with findings from who revealed an association between mortality and precipitation [95]. [39] Explored possible relationships between SARS-CoV-2 and Influenza infections with atmospheric variables and socio-economic conditions among tropical and subtropical climates in Brazil. The authors found that temperature combined with humidity were risk factors for COVID-19 and Influenza in both climate regimes, and the minimum temperature was also a risk factor for subtropical climate [39]. In addition, a cohort study conducted in 50 cities worldwide revealed that the distribution of COVID-19 outbreaks along restricted latitude, temperature, and humidity, resembled the circulation patterns of the seasonal respiratory viruses [96]. In contrast, studies carried out in China and in The United States $[93,97]$, did not find a clear correlation between environmental conditions and SARS-CoV-2 infection, in such a way that weather changes would not lead to a significant rise or decline in the number of infected cases [98-100]. Thus, it is still unclear if viral circulation is effectively associated to environmental and climate parameters and if SARS-CoV-2 will eventually become seasonal or will continue to circulate along all the year, as other RV.

\section{Conclusion}

Presumed factors that could drive the spread and severity of SARS-CoV-2 infection comprise the viral biology, genetic variability, fitness, stability, transmissibility and environmental persistence, natural and acquired hosts, virus-host interactions and anthropogenic interventions. Social determinants of health, including health equity, vaccine acceptance, and age-related illness, could play a role in disease occurrence and viral spread. Besides the demographic transition, climate changes compose a major Public Health challenge, with potential and relevant impact on the current epidemiological scenario. It favors the emergence/ reemergence of pathogens and the potential occurrence of outbreaks of distinct magnitude [101-105]. Therefore, efforts must be driven to categorically understand the relationships between SARS-CoV-2 infection, circulation patterns and climate parameters, as the putative implications of viral persistence and viability in distinct environmental matrices. This information is crucial for COVID-19 control and prevention, especially in middle and low-income settings, already wedged by social inequality, inadequate sanitation and deficient healthcare admission.

\section{Acknowledgements}

This research was funded by Oswaldo Cruz Foundation, Ministry of Health (MoH), The Health Surveillance Secretariat, SVS, MoH; the National Council for Scientific and Technological Development, CNPQ, grant number 402457/2020-0, the Research Support Foundation of the State of Rio de Janeiro, FAPERJ, grant number E-26/210.196/2020 and the National Institute in Science and Technology (INCT)-Climate Change Phase 2 (CNPq 465501/20141, FAPESP 2014/50848-9, CAPES 16/2014).

\section{Conflict of Interest}

The authors declare no conflict of interests.

\section{References}

1. Wu F, Zhao S, Yu B, Chen Y-M, Wang W, et al. (2020) A new coronavirus associated with human respiratory disease in China. Nature 579(7798): 265-269.

2. Zhou P, Yang X-L, Wang X-G, Hu B, Zhang L, et al. (2020) A pneumonia outbreak associated with a new coronavirus of probable bat origin. Nature 579(7836): 270-273.

3. World Health Organization WHO Director-General's opening remarks at the media briefing on COVID-19.

4. World Health Organization Coronavirus disease 2019 (COVID-19)Situation Report 190.

5. Johns Hopkins University COVID-19 Dashboard by the Center for Systems Science and Engineering (CSSE) 2020, USA.

6. Ferguson NM, Laydon D, Nedjati-Gilani G, Imai N, Ainslie K, et al. (2020) Impact of non-pharmaceutical interventions (NPIs) to reduce COVID- 19 mortality and healthcare demand. 20.

7. Imai N, Cori A, Dorigatti I, Baguelin M, Donnelly CA, et al. (2020) Report 3: Transmissibility of 2019-nCoV. London.

8. World Health Organization WHO Coronavirus Disease (COVID-19)

9. World Health Organization Weekly epidemiological update-8 December 2020 .

10. World Health Organization Modes of transmission of virus causing COVID-19: implications for IPC precaution recommendations.

11. Liu Y, Ning Z, Chen Y, Guo M, Liu Y, et al. (2020) Aerodynamic analysis of SARS-CoV-2 in two Wuhan hospitals. Nature 582: 557-560.

12. Van Doremalen N, Bushmaker T, Morris DH, Holbrook MG, Gamble A, et al. (2020) Aerosol and Surface Stability of SARS-CoV-2 as Compared with SARS-CoV-1. N Engl J Med 382(16):1564-1567.

13. Marquès M, Domingo JL (2021) Contamination of inert surfaces by SARSCoV-2: Persistence, stability and infectivity. A review. Environmental Research 193: 110559.

14. National Academies of Sciences, Engineering, and Medicine (2020) Rapid Expert Consultation on the Possibility of Bioaerosol Spread of SARS-CoV-2 for the COVID-19 Pandemic. National Academies Press: Washington, D.C. pp:25769, ISBN 978-0-309-67632-8.

15. Santarpia JL, Rivera DN, Herrera VL, Morwitzer MJ, Creager HM, et al. (2020) Aerosol and surface contamination of SARS-CoV-2 observed in quarantine and isolation care. Scientific Reports 10: 12732. 
16. Morawska L, Milton DK (2020) It Is Time to Address Airborne Transmission of Coronavirus Disease 2019 (COVID-19). Clin Infect Dis 71(9): 2311-2313.

17. Niazi S, Groth R, Spann K, Johnson GR (2020) The role of respiratory droplet physicochemistry in limiting and promoting the airborne transmission of human coronaviruses: A critical review. Environ Pollut 6: 115767.

18. The Lancet Respiratory Medicine COVID-19 transmission-up in the air (2020) Lancet Respir Med 8(12): 1159.

19. CDC Coronavirus Disease 2019 (COVID-19).

20. Park S-K, Lee C-W, Park D-I, Woo H-Y, Cheong HS, et al. (2020) Detection of SARS-CoV-2 in Fecal Samples from Patients with Asymptomatic and Mild COVID-19 in Korea. Clin Gastroenterol Hepatol S1542-3565(20): 30777-30801.

21. Xiao F, Sun J, Xu Y, Li F, Huang X, et al. (2020) Infectious SARS-CoV-2 in Feces of Patient with Severe COVID-19. Emerg Infect Dis 26: 1920-1922.

22. Xing Y-H, Ni W, Wu Q Li W-J, Li G-J, et al. (2020) Prolonged viral shedding in feces of pediatric patients with coronavirus disease 2019. Journal of Microbiology Immunology and Infect 53(3): 473-480.

23. Wang W, Xu Y, Gao R, Lu R, Han K, et al. (2020) Detection of SARS-CoV-2 in Different Types of Clinical Specimens. JAMA 323(18): 1843-1844.

24. Tian Y, Rong L, Nian W, He Y (2020) Review article: gastrointestinal features in COVID-19 and the possibility of faecal transmission. Aliment Pharmacol Ther 51(9): 843-851.

25. Ianiro G, Mullish BH, Kelly CR, Sokol H, Kassam Z, et al. (2020) Screening of faecal microbiota transplant donors during the COVID-19 outbreak: suggestions for urgent updates from an international expert panel. Lancet Gastroenterol Hepatol 5(5): 430-432.

26. Zhang Y, Chen C, Zhu S, Shu C, Wang D, et al. (2020) Isolation of 2019nCoV from a Stool Specimen of a Laboratory-Confirmed Case of the Coronavirus Disease 2019 (COVID-19). China CDC Weekly 2: 123-124.

27. Heller L, Mota CR, Greco DB (2020) COVID-19 faecal-oral transmission: Are we asking the right questions? Science of The Total Environment Volume 729: 138919.

28. Amirian ES (2020) Potential Fecal Transmission of SARS-CoV-2: Current Evidence and Implications for Public Health. International Journal of Infectious Diseases 95: 363-370.

29. Kim J-M, Kim HM, Lee EJ, Jo HJ, Yoon Y, et al. (2020) Detection and Isolation of SARS-CoV-2 in Serum, Urine, and Stool Specimens of COVID-19 Patients from the Republic of Korea. Osong Public Health Res Perspect 11(13): 112-117.

30. Wölfel R, Corman VM, Guggemos W, Seilmaier M, Zange S, et al. (2020) Virological assessment of hospitalized patients with COVID-2019. Nature 581(7809): 465-469.

31. Aguiar-Oliveira M de L, Campos A, Matos A, Rigotto C, Sotero-Martins A. et al. (2020) Wastewater-Based Epidemiology (WBE) and Viral Detection in Polluted Surface Water: A Valuable Tool for COVID-19 Surveillance-A Brief Review. Int J Environ Res Public Health 17(24): 9251.

32. Medema G, Heijnen L, Elsinga G, Italiaander R, Brouwer A, et al. (2020) Presence of SARS-Coronavirus-2 RNA in Sewage and Correlation with Reported COVID-19 Prevalence in the Early Stage of the Epidemic in The Netherlands. Environ Sci Technol Lett 7: 511-516.

33. La Rosa G, Iaconelli M, Mancini P, Bonanno Ferraro G, Veneri C, et al. (2020) First detection of SARS-CoV2 in untreated wastewaters in Italy. Sci Total Environ736: 139652

34. Ahmed W, Angel N, Edson J, Bibby K, Bivins A, et al. (2020) First confirmed detection of SARS-CoV-2 in untreated wastewater in Australia: A proof of concept for the wastewater surveillance of COVID-19 in the community. Sci Total Environ 728: 138764
35. (2020) Centro Estadual de Vigilância em Saúde do Estado do Rio Grande do Sul Monitoramento ambiental de SARS-CoV-2. Boletim de acompanhamento.

36. Wu F, Xiao A, Zhang J, Moniz K, Endo N, et al. (2020) SARS-CoV-2 titers in wastewater foreshadow dynamics and clinical presentation of new COVID-19 cases. medRxiv.

37. Blanco Fernández MD, Barrios ME, Cammarata RV, Torres C, Taboga OA, et al. (2017) Comparison of internal process control viruses for detection of food and waterborne viruses. Appl Microbiol Biotechnol 101(10): 4289-4298.

38. Kifer D, Bugada D, Villar-Garcia J, Gudelj I, Menni C, et al. (2020) Effects of environmental factors on severity and mortality of COVID-19. medRxiv.

39. Martins LD, da Silva I, Batista WV, Andrade M de F, Freitas ED de, et al. (2020) How socio-economic and atmospheric variables impact COVID-19 and influenza outbreaks in tropical and subtropical regions of Brazil. Environ Res 191: 110184.

40. Ma Y, Zhao Y, Liu J, He X, Wang B, et al. (2020) Effects of temperature variation and humidity on the death of COVID-19 in Wuhan, China. Science of The Total Environment 724: 138226.

41. Smit AJ, Fitchett JM, Engelbrecht FA, Scholes RJ, Dzhivhuho G, et al. (2020) Winter Is Coming: A Southern Hemisphere Perspective of the Environmental Drivers of SARS-CoV-2 and the Potential Seasonality of COVID-19. Int J Environ Res Public Health 17(16): 5634.

42. World Health Organization Consensus document on the epidemiology of severe acute respiratory syndrome (SARS) 2003.

43. Lai MYY, Cheng PKC, Lim WWL (2005) Survival of severe acute respiratory syndrome coronavirus. Clin Infect Dis 41(7): e67-e71.

44. Wang XW, Li J, Guo T, Zhen B, Kong Q et al. (2005) Concentration and detection of SARS coronavirus in sewage from Xiao Tang Shan Hospital and the 309 th Hospital of the Chinese People's Liberation Army. Water Sci Technol 52(8): 213-221.

45. Casanova L, Rutala WA, Weber DJ, Sobsey MD (2009) Survival of surrogate coronaviruses in water. Water Research 43: 1893-1898.

46. Carraturo F, Del Giudice C, Morelli M, Cerullo V, Libralato G, et al. (2020) Persistence of SARS-CoV-2 in the environment and COVID-19 transmission risk from environmental matrices and surfaces. Environ Pollut 265: 115010

47. Carducci A, Federigi I, Liu D, Thompson JR, Verani M, et al. (2020) Making Waves: Coronavirus detection, presence and persistence in the water environment: State of the art and knowledge needs for public health. Water Research 179: 115907

48. La Rosa G, Bonadonna L, Lucentini L, Kenmoe S, Suffredini E, et al (2020) Coronavirus in water environments: Occurrence, persistence and concentration methods - A scoping review. Water Research 179: 115899

49. Yap TF, Liu Z, Shveda RA, Preston DJ (2020) A predictive model of the temperature-dependent inactivation of coronaviruses. Applied Physics Letters 117: 060601.

50. Chin A, Chu J, Perera M, Hui K, Yen H-L, et al. (2020) Stability of SARS$\mathrm{CoV}-2$ in different environmental conditions. medRxiv.

51. Sun Z, Thilakavathy K, Kumar SS, He G, Liu SV (2020) Potential Factors Influencing Repeated SARS Outbreaks in China. Int J Environ Res Public Health 17(5): 1633.

52. Geller C, Varbanov M, Duval RE (2012) Human Coronaviruses: Insights into Environmental Resistance and Its Influence on the Development of New Antiseptic Strategies. Viruses 4(11): 3044-3068.

53. O’Brien E, Xagoraraki I (2019) Wastewater-Based Epidemiology for Early Detection of Viral Outbreaks. In Women in Engineering and Science; Women in Water Quality; O’Bannon D 7: ISBN 978-3-030-17819-2. 
54. Wurtzer S, Marechal V, Mouchel J-M, Moulin L (2020) Time course quantitative detection of SARS-CoV-2 in Parisian wastewaters correlates with COVID-19 confirmed cases. medRxiv.

55. Guerrero-Latorre L, Ballesteros I, Villacrés-Granda I, Granda MG, FreirePaspuel B, et al. (2020) SARSCoV-2 in river water: Implications in low sanitation countries. Sci Total Environ 743: 140832.

56. Rimoldi SG, Stefani F, Gigantiello A, Polesello S, Comandatore F, et al. (2020) Presence and infectivity of SARS-CoV-2 virus in wastewaters and rivers. Science of The Total Environment 744: 140911.

57. World Health Organization Water, sanitation, hygiene and waste management for COVID-19.

58. Döhla M, Wilbring G, Schulte B, Kümmerer BM, Diegmann C, et al. (2020) SARS-CoV-2 in environmental samples of quarantined households. medRxiv.

59. Wang J, Feng H, Zhang S, Ni Z, Ni L, et al. (2020) SARS-CoV-2 RNA detection of hospital isolation wards hygiene monitoring during the Coronavirus Disease 2019 outbreak in a Chinese hospital. International Journal of Infectious Diseases 94: 103-106.

60. Elsamadony M, Fujii M, Miura T, Watanabe T (2021) Possible transmission of viruses from contaminated human feces and sewage: Implications for SARS-CoV-2. Sci Total Environ 755: 142575.

61. Adelodun B, Ajibade FO, Ibrahim RG, Bakare HO, Choi K-S, et al. (2020) Snowballing transmission of COVID-19 (SARS-CoV-2) through wastewater: Any sustainable preventive measures to curtail the scourge in low-income countries? Sci Total Environ 742: 140680.

62. Odih EE, Afolayan AO, Akintayo I, Okeke IN (2020) Could Water and Sanitation Shortfalls Exacerbate SARS-CoV-2 Transmission Risks? Am J Trop Med Hyg 103(2): 554-557.

63. Han J, He S (2021) Urban flooding events pose risks of virus spread during the novel coronavirus (COVID19) pandemic. Sci Total Environ 755: 142491

64. Street R, Malema S, Mahlangeni N, Mathee A (2020) Wastewater surveillance for Covid-19: An African perspective. Science of The Total Environment 43: 140719.

65. Gwenzi W (2021) Leaving no stone unturned in light of the COVID-19 faecal-oral hypothesis? A water, sanitation and hygiene (WASH) perspective targeting low-income countries. Science of The Total Environment 753: 141751.

66. World Health Organization; United Nations World Water Development Report 2017.

67. Ten Veldhuis JaE, Clemens FHLR, Sterk G, Berends BR (2010) Microbial risks associated with exposure to pathogens in contaminated urban flood water. Water Res 44: 2910-2918.

68. Olds HT, Corsi SR, Dila DK, Halmo KM, Bootsma MJ, et al. (2018) High levels of sewage contamination released from urban areas after storm events: A quantitative survey with sewage specific bacterial indicators. PLOS Medicine.

69. Abdel-Moneim AS, Abdelwhab EM (2020) Evidence for SARS-CoV-2 Infection of Animal Hosts. Pathogens 9(7): 529.

70. Shi J, Wen Z, Zhong G, Yang H, Wang C, et al. (2020) Susceptibility of ferrets, cats, dogs, and other domesticated animals to SARS-coronavirus 2. Science 368(6494):1016-1020.

71. Oreshkova N, Molenaar RJ, Vreman S, Harders F, Oude Munnink BB, et al. (2020) SARS-CoV-2 infection in farmed minks, the Netherlands, April and May 2020 Euro Surveill 25(23): 2001005.

72. Enserink M (2020) Coronavirus rips through Dutch mink farms, triggering culls. Science 368(6496): 1169
73. Franklin AB, Bevins SN (2020) Spillover of SARS-CoV-2 into novel wild hosts in North America: A conceptual model for perpetuation of the pathogen. Science of The Total Environment 733: 139358.

74. Moura FEA, Perdigão ACB, Siqueira MM (2009) Seasonality of influenza in the tropics: a distinct pattern in northeastern Brazil. Am J Trop Med Hyg 81(1): 180-183.

75. Moriyama M, Hugentobler WJ, Iwasaki A (2020) Seasonality of Respiratory Viral Infections. Annu Rev Virol 7(1): 83-101.

76. Neher RA, Dyrdak R, Druelle V, Hodcroft EB, Albert J, et al. (2020) Potential impact of seasonal forcing on a SARS-CoV-2 pandemic. Swiss Med Wkly 150: w20224.

77. Metz JA, Finn A (2015) Influenza and humidity - Why a bit more damp may be good for you! J Infection 71Supply 1: S54-S58.

78. Tang JW, Loh TP (2014) Correlations between climate factors and incidence-a contributor to RSV seasonality: Climate factors and RSV infections. Rev Med Virol 24(1): 15-34.

79. Almeida A, Codeço C, Luz PM (2018) Seasonal dynamics of influenza in Brazil: the latitude effect. BMC Infect Dis 18(1): 695

80. Price RHM, Graham C, Ramalingam S (2019) Association between viral seasonality and meteorological factors. Scientific Reports 9: 929.

81. Alonso WJ, Viboud C, Simonsen L, Hirano EW, Daufenbach LZ, et al. (2007) Seasonality of influenza in Brazil: a traveling wave from the Amazon to the subtropics. Am J Epidemiol 165(12): 1434-1442.

82. Birrell PJ, Zhang X-S, Corbella A, van Leeuwen E, Panagiotopoulos N, et al. (2020) Forecasting the 2017/2018 seasonal influenza epidemic in England using multiple dynamic transmission models: a case study. BMC Public Health 20(1): 486.

83. Zambon M (2014) Influenza and other emerging respiratory viruses. Medicine 42(1): 45-51.

84. Chadha M, Hirve S, Bancej C, Barr I, Baumeister E, et al. (2020) Human respiratory syncytial virus and influenza seasonality patterns-Early findings from the WHO global respiratory syncytial virus surveillance. Influenza Other Respi Viruses 14: 638-646.

85. Caini S, Andrade W, Badur S, Balmaseda A, Barakat A, et al. (2016) Correction: Temporal Patterns of Influenza A and B in Tropical and Temperate Countries: What Are the Lessons for Influenza Vaccination? PLOS One 11(5): e0155089.

86. Caini S, Spreeuwenberg P, Donker G, Korevaar J, Paget J, et al. (2018) Climatic factors and long-term trends of influenza-like illness rates in The Netherlands, 1970-2016. Environ Res 167: 307-313.

87. Baker RE, Mahmud AS, Wagner CE, Yang W, Pitzer VE, et al. (2019) Epidemic dynamics of respiratory syncytial virus in current and future climates. Nat Commun 10(1): 5512

88. Su S, Wong G, Shi W, Liu J, Lai ACK, et al. (2016) Epidemiology, Genetic Recombination, and Pathogenesis of Coronaviruses. Trends in Microbiology 24: 490-502.

89. Li Y, Ye X, Zhou J, Zhai F, Chen J, et al. (2020) The association between the seasonality of pediatric pandemic influenza virus outbreak and ambient meteorological factors in Shanghai. Environ Health 19(1): 71.

90. Suntronwong N, Vichaiwattana P, Klinfueng S, Korkong S, Thongmee T, et al. (2020) Climate factors influence seasonal influenza activity in Bangkok, Thailand. PLOS ONE 15: e0239729.

91. Tamerius JD, Shaman J, Alonso WJ, Alonso WJ, Bloom-Feshbach K, et al. (2013) Environmental predictors of seasonal influenza epidemics across temperate and tropical climates. PLoS Pathog 9(3): e1003194. 
92. Thongpan I, Vongpunsawad S, Poovorawan Y (2020) Respiratory syncytial virus infection trend is associated with meteorological factors. Scientific Reports 10: 10931.

93. Poirier C, Luo W, Majumder MS, Liu D, Mandl KD, et al. (2020) The role of environmental factors on transmission rates of the COVID-19 outbreak: an initial assessment in two spatial scales. Sci Rep 10(1): 17002.

94. Sooryanarain H, Elankumaran S (2015) Environmental Role in Influenza Virus Outbreaks. Annu Rev Anim Biosci 3: 347-373.

95. Sobral MFF, Duarte GB, da Penha Sobral AIG, Marinho MLM, de Souza Melo A, et al. (2020) Association between climate variables and global transmission oF SARS-CoV-2. Sci Total Environ 729: 138997.

96. Sajadi MM, Habibzadeh P, Vintzileos A, Shokouhi S, Miralles-Wilhelm F, et al. (2020) Temperature, Humidity, and Latitude Analysis to Estimate Potential Spread and Seasonality of Coronavirus Disease 2019 (COVID-19). JAMA Netw Open 3: e2011834.

97. Chien L-C, Chen LW (2020) Meteorological impacts on the incidence of COVID-19 in the U.S. Stoch Environ Res Risk Assess 1-6.

98. Adedokun KA, Olarinmoye AO, Mustapha JO, Kamorudeen RT (2020) A close look at the biology of SARSCoV-2, and the potential influence of weather conditions and seasons on COVID-19 case spread. Infect Dis Poverty 9: 77.
99. Bukhari Q, Massaro JM, D’Agostino RB, Khan S (2020) Effects of Weather on Coronavirus Pandemic. Int J Environ Res Public Health 17(15): 5399.

100. Islam N, Bukhari Q Jameel Y, Shabnam S, Erzurumluoglu AM, et al. (2020) COVID-19 and climatic factors: A global analysis. Environmental Research 110355.

101. Viboud C, Pakdaman K, Boëlle P-Y, Wilson ML, Myers MF, et al. (2004) Association of influenza epidemics with global climate variability. Eur J Epidemiol 19(11): 1055-1059.

102. Elliott RM (2009) Bunyaviruses and climate change. Clin Microbiol Infect 15(6): 510-517.

103. Stark K, Niedrig M, Biederbick W, Merkert H, Hacker J, et al. (2009) Climate changes and emerging diseases. What new infectious diseases and health problem can be expected? Bundesgesundheitsblatt Gesundheitsforschung Gesundheitsschutz 52(7): 699-714.

104. Moirano G, Gasparrini A, Acquaotta F, Fratianni S, Merletti F, et al. (2018) West Nile Virus infection in Northern Italy: Case-crossover study on the short-term effect of climatic parameters. Environ Res 167: 544-549.

105. Tabachnick WJ (2016) Climate Change and the Arboviruses: Lessons from the Evolution of the Dengue and Yellow Fever Viruses. Annu Rev Virol 3(1): 125-145. 